\title{
GAP-43 Amino Terminal Peptides Modulate Growth Cone Morphology and Neurite Outgrowth
}

\author{
Stephen M. Strittmatter, Michihiro Igarashi, ${ }^{a}$ and Mark C. Fishman \\ Developmental Biology Laboratory, Massachusetts General Hospital, and Departments of Neurology and Medicine, \\ Harvard Medical School, Massachusetts General Hospital-East, Charlestown, Massachusetts 02129
}

The neuronal growth-associated protein GAP-43 is expressed maximally during development and regeneration, and is enriched at the cytosolic surface of the growth cone membrane. GAP-43 can activate the GTP-binding protein $\mathbf{G}_{0}$, which is also a major component of the growth cone membrane. These findings have led to the hypothesis that GAP. 43 might modulate neurite outgrowth by altering G-protein activity.

Here we define the sequence requirements for GAP-43 amino terminal peptide stimulation of $G_{0}$, and test these peptides as potential modulators of neurite outgrowth. The first 10 amino acids of GAP-43, Met-Leu-Cys-Cys-Met-Arg-ArgThr-Lys-GIn, stimulate $\mathbf{G}_{0}$. Substitutions at particular residues reveal that cys3, cys4, arg6, and lys9 are critical, but $\arg 7$ is not.

Both the GAP-43(1-10) peptide and the G-protein-activating peptide mastoparan induce growth cone collapse and inhibit neurite extension from embryonic chick dorsal root ganglion and retinal neurons. This is likely to be mediated by G-proteins: pertussis toxin blocks the inhibition, and mutant peptides that do not activate $G_{0}$ do not alter outgrowth. In contrast to the case with embryonic chick dorsal root ganglion cells, neurite outgrowth from N1E-115 neuroblastoma cells is stimulated by GAP-43(1-10). This is probably also a G-protein-mediated event because it is blocked by pertussis toxin, because the sequence requirements match those for $\mathrm{G}_{0}$ stimulation, and because mastoparan stimulates outgrowth from these cells. The longer GAP-43(1-25) peptide does not alter neurite outgrowth unless the cells are permeabilized, suggesting an intracellular site of action.

These data identify a novel set of compounds that modulate neurite outgrowth, and also support the notion that GAP-43 can alter neurite extension by modulating pertussis toxin-sensitive G-protein activity in the growth cone.

[Key words: growth-associated protein-43, neuromodulin,

\footnotetext{
Received July 9, 1993; revised Feb. 21, 1994; accepted Mar. 2, 1994.

We thank Xaio-Ping Zhu, Ling $\mathrm{Li}$, and Margaret Boulos for expert technical assistance. This work is supported by Grants K08NS01467 and RO1NS33020 from the National Institutes of Health to S.M.S., an Overseas Research Fellowship from Uehara Mernorial Foundation to M.I., and a grant from Sumitomo Chemical and Pharmaceutical Cos. to M.C.F.

Correspondence should be addressed to Stephen M. Strittmatter, Department of Neurology, Yale University School of Mcdicinc, P.O. Box 208018, New Haven, CT 06520.

a Present address: Department of Molecular and Cellular Neurobiology, Gumma University School of Medicine, Macbashi, Gumma 371, Japan.

Copyright $(1994$ Society for Neuroscience $0270-6474 / 94 / 145503-11 \$ 05.00 / 0$
}

GTP-binding protein, neurite outgrowth, growth cone collapse, pertussis toxin, mastoparan, dorsal root ganglion, neuroblastoma cells!

The growth-associated protein GAP-43 (also referred to as neuromodulin, $\mathrm{F} 1$ or $\mathrm{B} 50$ ) is a neuronal protein that is enriched on the inner surface of the growth cone membrane, and may be crucial for nerve growth (reviewed in Benowitz and Routtenberg, 1987; Skene, 1989; Strittmatter and Fishman, 1991). It is expressed by most, if not all, developing and regenerating neurons during periods of axonal extension. Neurite extension from NGF-stimulated PC1 2 cells is enhanced by transfection with a human GAP-43 expression vector (Yankner et al., 1990). However, GAP-43 is neither necessary nor sufficient for neurite elongation, since PC1 2 clones lacking GAP-43 can extend processes (Baetge and Hammang, 1991) and certain adult neurons express high levels of GAP-43 after axonal elongation ceases (Benowitz et al., 1987). A modification of the original growth-related thesis is that GAP-43 does not cause axonal extension per se, but rather plays a role in modulating nerve terminal plasticity, perhaps by regulating signal transduction at the membrane (Strittmatter et al., 1992).

Evidence of the interaction of GAP-43 with transduction machinery includes its ability in vitro to activate certain G-proteins (Strittmatter et al., 1990, 1991), to inhibit phosphatidyl-inositol-4-phosphate kinase (Oestricher et al., 1983) and to bind calmodulin (Alexander et al., 1987). GAP-43 is a substrate for protein kinase C (Coggins and Zwiers, 1989), and phosphorylation by protein kinase $C$ interferes with calmodulin binding, as do increased calcium levels (Alexander et al., 1987). Amino acid residues 39-55 constitute the calmodulin-binding domain (Alexander et al., 1988), and the serine at position 41 is the protein kinase $C$ phosphorylation site (Coggins and Zwiers, 1989).

The pertussis toxin-sensitive $G$-proteins, $G_{0}$ and $G_{i}$, are the most prominent noncytoskeletal components of the growth cone membrane (Strittmatter et al., 1990). Pertussis toxin-sensitive $\mathrm{G}$-proteins have been shown to regulate nerve growth. For cxample, GDP $\beta$ S enhances growth of cultured embryonic chick sympathetic neurons (Strittmatter et al., 1992). The growth cone collapsing activity of myelin and of embryonic brain membranes is blocked by pertussis toxin (Igarashi et al., 1993). Expression of activated mutants of the $\alpha$ subunit of $\mathrm{G}_{0}$ increases neurite outgrowth from neuroblastoma and pheochromocytoma cells (Strittmatter et al., 1994a).

Indirect data led to the hypothesis that GAP-43 alters growth cone motility by activating G-proteins and enhancing their sensitivity to extracellular growth regulators (Strittmatter, 1992). 
Table 1. GAP-43-derived peptides in this study

\begin{tabular}{llll} 
Peptide & Abbreviation & Stimulates $\mathrm{G}_{\text {o }}$ & $\begin{array}{c}\text { Alters } \\
\text { neurite outgrowth }\end{array}$ \\
\hline MLCCMRRTKQVEKNDEDQKIEQDG & $1-25$ & ++ (Sudo et al., 1992) & - (nonpermeable) \\
& & & + (permeable) \\
MLCCMRRTKQ & $1-10$ & ++ (Fig. 1) & ++ \\
MLCCMGRTKQ & $1-10 \mathrm{R} 6$ & - (Fig. 1) & - \\
MLCCMRGTKQ & $1-10 \mathrm{R} 7$ & + (Fig. 1) & + \\
MLCCMRRTGQ & $1-10 \mathrm{~K} 9$ & - (Fig. 1) & - \\
MLTTMRRTKQ & $1-10 \mathrm{C} 3 \mathrm{C} 4$ & - (Sudo et al., 1992) & - \\
MLCCMR & $1-6$ & - (Strittmatter et al., 1990) & - \\
DEKKGDAPAAEAEAKEK & $\mathrm{A}(53-69)$ & - (Strittmatter et al., 1990) & - \\
ARQDEFKEDPEADQEHA & $\mathrm{B}(210-226)$ & &
\end{tabular}

Purified GAP-43 activates $\mathrm{G}_{\mathrm{o}}$ and $\mathrm{G}_{\mathrm{i}}$ (Strittmatter et al., 1990, 1991). It does so by enhancing GDP release, with consequent increase in GTP binding, a mechanism similar to that of G-protein-coupled receptors. In Xenopus oocytes, microinjection of GAP-43 directly stimulates a G-protein cascade (Strittmatter et al., 1993a). At low concentrations, GAP-43 greatly augments receptor activation of this $\mathrm{G}$-protein-dependent signaling pathway (Strittmatter et al., 1993). The ability of GAP-43 transfection to induce morphologic changes in non-neuronal cells (Zuber et al., 1989b) is dependent on the G-protein-activating domain of the protein (Strittmatter et al., 1994a) and is associated with changes in cAMP levels, which suggest that $G_{i}$ is activated by GAP-43 expression (Strittmatter et al., 1994b).

Peptides composed of the GAP-43 amino terminal sequence activate G-proteins (Strittmatter et al., 1990; Sudo et al., 1992), although they are less potent than the intact protein. A peptide composed of the GAP-43 sequences $1-10$ or $1-25$ can activate $G_{0}$ to the same degree as can native GAP-43 (Sudo et al., 1992). [The GAP-43(1-10) peptide inhibits $G_{0}$ if oxidized, but is stimulatory if stored under reducing conditions.] Replacement of the cysteines in the GAP-43(1-10) peptide by threonine abrogates its stimulatory activity (Strittmatter et al., 1990), as does palmitoylation (Sudo et al., 1992), which is a naturally occurring posttranslational modification (Skene and Virag, 1989). The palmitoylation of these cysteines is required for the membrane association of the GAP-43 protein (Skene and Virag, 1989; Zuber et al., 1989b; Liu et al., 1991). Because these peptides can be readily synthesized and can substitute for the protein in $G_{0}$ activation assays, we sought to test whether they might affect growth cone physiology. If these peptides were to alter aspects of neuronal growth, they would constitute a novel means to modify growth cone behavior and their action would support the model of G-protein activation by GAP-43 in the growth cone.

Here we have better defined the G-protein-activating domain of GAP-43 by examining a number of amino-terminal peptides in which individual amino acids have been changed. The native GAP-43 amino-terminal decapeptide causes collapse of growth cones of dorsal root ganglion and retinal neurons, and inhibits their growth. In contrast, it stimulates process extension from neuroblastoma cells. These effects are blocked by pertussis toxin, implicating a G-protein-dependent mechanism of action. In addition, the rank order of potency for the mutant peptides as growth regulators correlates well with their potency as G-protein stimulators. It appears that the peptides act intracellularly, be- cause a longer GAP-43(1-25) peptide is without effect on neuronal morphology unless cells are permeabilized. These data describe a ncw class of ncuritc outgrowth regulators and have implications for the mechanism of GAP-43 protein function.

\section{Materials and Methods}

GAP-43 peptides. All GAP-43 peptides were chemically synthesized and the composition was verified by amino acid analysis and mass spectrometry (Sumitomo Chemical and Pharmaceutical Cos., and Nuros Corp.). Solutions were prepared in phosphate-buffered saline (PBS), 1 mM dithiothrietol (DTT) just prior to use. Three separate GAP-43(110) preparations maintained their ability to stimulate $G_{o}$, and their elution profile on reverse phase HPLC when stored in PBS, 1 mM DTT at $-20^{\circ} \mathrm{C}$. However, when stored without DTT, the HPLC elution profile was altered (Sudo et al., 1992), and the GAP-43(1-10) peptide inhibited GTP $S$ binding to $\mathrm{G}_{\mathrm{o}}$ (Strittmatter et al., 1990).

$G T P \gamma S$ binding to $G_{o}$. The activation state of $\mathrm{G}_{\mathrm{o}}$ was monitored by the binding of ${ }^{35}$ S-GTP $\gamma$ S to purified bovine brain $G_{o}$ in a nitrocellulose filtration assay as described in detail previously (Strittmatter et al., 1990, 1991). For kinetic assays, tubes with $100 \mu \mathrm{M}$ GAP-43 peptides and 10 nM $G_{0}$ were prepared on ice, and then assays were initiated by adding ${ }^{35} \mathrm{~S}-\mathrm{GTP} \gamma \mathrm{S}$ to $40 \mathrm{nM}$ and incubating for various times at $23^{\circ} \mathrm{C}$ before filtration. Initial rates were determined from measurements made during the first $1-4 \mathrm{~min}$ of incubation at $23^{\circ} \mathrm{C}$. In some assays, the $G_{\circ}$ preparation had been pretreated with pertussis toxin (PTX) in the presence of NAD, as described previously (Strittmatter et al., 1991). These PTX reaction conditions result in complete ADP-ribosylation of $G_{o}$ (Strittmatter et al., 1991).

Embryonic dorsal root ganglion cell culture, growth cone collapse, and neurite outgrowth. Dorsal root ganglia were removed from embryonic day 7 chick embryos and explanted onto laminin-coated slides in F12 medium with $5 \mathrm{ng} / \mathrm{ml}$ nerve growth factor and $10 \%$ fetal calf serum. Peptide solutions or PBS, $1 \mathrm{~mm}$ DTT control buffer $(50 \mu \mathrm{l})$ was added to explants in culture medium $(500 \mu \mathrm{l})$ and the mixture incubated at $37^{\circ} \mathrm{C}$ for $30 \mathrm{~min}$ prior to fixation in $4 \%$ paraformaldehyde in PBS. For each explant, all growth cones were then characterized as collapsed or spread as described previously (Igarashi et al., 1993). In some cases, PTX $(100 \mathrm{ng} / \mathrm{ml})$ was added to the medium $2 \mathrm{hr}$ prior to the addition of the peptide solution.

Dissociated cell cultures were prepared from embryonic DRGs treated with $0.25 \%$ trypsin, $1 \mathrm{~mm}$ EDTA for $15 \mathrm{~min}$ at $37^{\circ} \mathrm{C}$. The tissue was then triturated 30 times in growth medium using a fire-polished Pasteur pipette. The material was preplated on untreated plastic for $2 \mathrm{hr}$ to allow non-neuronal cells to attach, and then the free-floating cells were plated onto laminin-coated slides in the presence of $1 / 10$ vol of GAP -43 peptides or buffer. After $6 \mathrm{hr}$ of culture at $37^{\circ} \mathrm{C}$, cells were fixed with $4 \%$ paraformaldehyde in PBS, and the fraction of neurons with a process longer than $20 \mu \mathrm{m}$ was determined.

In some experiments, the DRG neurons were triturated 50 times in medium with or without $50 \mu \mathrm{M}$ GAP-43 peptide just prior to plating, and then the dissociated cells were cultured in the presence or absence of $10 \mu \mathrm{M}$ GAP-43 peptide. This is a modification of the method cmployed for p21 ras (Borasio et al., 1989). 
A

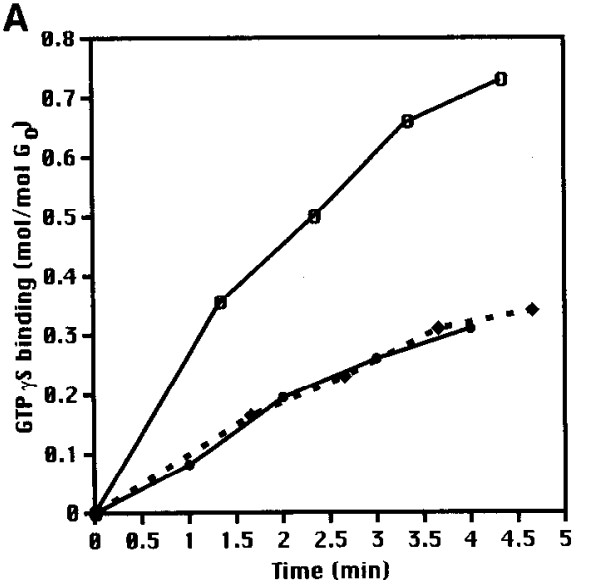

B


Figure 1. Characterization of GAP-43(1-10) peptide stimulation of GTP $\gamma \mathrm{S}$ binding to $\mathrm{G}_{\mathrm{o}} . A$, Time course of ${ }^{35} \mathrm{~S}-\mathrm{GTP} \gamma \mathrm{S}$ binding to $\mathrm{G}_{\mathrm{o}}$ in the presence of GAP-43(1-10) peptides. ${ }^{35}$ S-GTP $\gamma$ binding to $G_{0}$ was measured after incubation at $23^{\circ} \mathrm{C}$ for the indicated times in the presence of buffer (0), $100 \mu \mathrm{M}$ GAP-43(1-10) peptide (O), or $100 \mu \mathrm{M} 1-10 \mathrm{R} 6$ peptide ( ). Note that binding is linearly related to time over this period and that, whereas the $1-10$ peptide stimulates $G_{0}$, the 1-10R6 peptide has no effect. This is one of four experiments with similar results. $B$, Initial rate of ${ }^{35} \mathrm{~S}-\mathrm{GTP}_{\gamma} \mathrm{S}$ binding to $\mathrm{G}_{\circ}$ in the presence of GAP-43(110) peptides. The initial rate of ${ }^{35} \mathrm{~S}-\mathrm{GTP} \gamma \mathrm{S}$ binding to $\mathrm{G}_{\mathrm{o}}$ after $1-4 \mathrm{~min}$ at $23^{\circ} \mathrm{C}$ was determined in the presence of $100 \mu \mathrm{M}$ concentrations of the indicated peptides. The wild-type 1-10 sequence stimulated binding to $\mathrm{G}_{\text {o }}$, as described previously (Sudo et al., 1992). The 1-10 R7 mutant was nearly as effective in stimulating $G_{0}$. In contrast, the $1-10 \mathrm{~K} 9$ and the 1-10 R6 mutant peptides were much less effective stimulators of $G_{0}$. The values shown are the means $\pm S E M$ for four separate experi-
Retinal neuron culture and growth cone collapse. Chick embryonic day 7 temporal retina was cut into small pieces and explanted as described for DRG cultures. Growth cone collapse in the presence of GAP$43(1-10)$ was assayed as described above.

Neuroblastoma cell culture, neurite outgrowth, and cell permeabilization. N1E- 115 cells were routinely cultured in F-12 medium with $10 \%$ fetal bovine serum. To induce neuronal differentiation, $2 \%$ DMSO was added to the medium for a period of 7-10 d. After this treatment, the cells were trypsinized $\left(0.25 \%\right.$ trypsin, $\left.5 \mathrm{~min}, 23^{\circ} \mathrm{C}\right)$ and replated onto glass chamber slides precoated sequentially with $0.1 \mathrm{mg} / \mathrm{ml}$ poly-Llysine for $1 \mathrm{hr}$ at $23^{\circ} \mathrm{C}$, and $10 \mu \mathrm{g} / \mathrm{ml}$ laminin for $1 \mathrm{hr}$ at $23^{\circ} \mathrm{C}$. Onetenth volume of various GAP-43 peptides in PBS, 1 mM DTT or PBS, $1 \mathrm{~mm}$ DTT alone was added at the time of plating. After $4 \mathrm{hr}$ of incubation at $37^{\circ} \mathrm{C}$, the cells were fixed with PBS, $2 \%$ glutaraldehyde, $12 \%$ sucrose for $10 \mathrm{~min}$ at $23^{\circ} \mathrm{C}$, and then stained with Coomassie blue. Consecutive cells in randomly chosen fields were photographed using a video processor and neurite extension was quantitated by an observer unaware of the experimental protocol. In some cases, total neurite length for each cell was determined, and in other experiments cells were scored positive if the longest cellular process exceeded one cell diameter.

The permeabilization procedure is identical to that described previously for mouse neuroblastoma cells by Shea et al. (1991). Permeabilization is achieved by incubation with $1.2 \mathrm{M}$ glycerol and then $40 \mu \mathrm{g} /$ $\mathrm{ml}$ phosphatidylcholine at $4^{\circ} \mathrm{C}$. GAP-43 peptides were added immediately after the permeabilization and then the cultures were incubated as for nonpermeabilized cells.

Statistical analysis. Results were compared by means of a two-tailed Student's $t$ test.

\section{Results}

Definition of the $G_{o}$ stimulating domain of GAP-43

We synthesized several variant GAP-43(1-10) peptides in order to examine the importance of the different amino acids upon G-protein intcraction (Table 1). Bccausc the array of three basic charges in GAP-43 resembles an important component of the $\mathrm{G}$-protein-activating region of $\mathrm{G}$-coupled receptors (Okamoto et al., 1990, 1991a), we focused upon these residues at positions 6,7 , and 9. There is no stimulation of GTP $\gamma S$ binding to $G_{o}$ with a shorter peptide (1-6), which lacks two of these residues, as reported previously (Sudo et al., 1992). The first and third basic residues appear to be critical for stimulation of the initial rate of $\mathrm{GTP}_{\gamma} \mathrm{S}$ binding to $\mathrm{G}_{\mathrm{o}}$ (Fig. $1 A, B$ ). Substitution for the arginine at position 6 (R6) or the lysine at position 9 (K9) markedly reduces the activity when compared to GAP-43(110). In contrast, substitution at position 7 (R7) produces little change in $G_{0}$ stimulation, even though the amino acid composition of this peptide is identical to the R6 peptide.

Pertussis toxin (PTX) ADP-ribosylates the $\alpha$-subunit of $\mathrm{G}_{0}$ and prevents activation by receptor-ligand complexes (Gilman, 1987). PTX pretreatment of $G_{o}$ also diminishes peptide stimulation of $\mathrm{GTP} \gamma \mathrm{S}$ binding by shifting the $\mathrm{EC}_{50}$ approximately threefold (Fig. 1C). There is a PTX-insensitive component of $\mathrm{G}_{\mathrm{o}}$ stimulation above $100 \mu \mathrm{M}$ peptide, but in the range used for the assays of neurite outgrowth described below, nearly all peptide stimulation of $\mathrm{G}_{\mathrm{o}}$ is blocked by PTX.

\footnotetext{
ments. ${ }^{35} \mathrm{~S}-\mathrm{GTP} \gamma \mathrm{S}$ binding was significantly increased by the $1-10$ and $1-10 \mathrm{R} 7$ peptides as compared to the buffer control $(p<0.01)$. $C$, PTX sensitivity of peptide stimulation. ${ }^{35}$ S-GTP $\gamma \mathrm{S}$ binding to purified bovine brain $G_{0}$ was assessed in the presence of the indicated concentrations of GAP-43(1-10) peptide. The $G_{0}$ preparation had been pretreated with pertussis toxin $(P T X, O)$ or not pretreated $(\bullet)$ prior to the binding assay. Note that pertussis toxin pretreatment shifts the dose response curve for the GAP-43(1-10) peptide stimulation of $G_{o}$ by at least a factor of 3 . The values shown are the means \pm SEM for five separate experiments. At $67 \mu \mathrm{M}$ GAP-43(1-10), PTX treatment decreased ${ }^{35} \mathrm{~S}-\mathrm{GTP} \gamma \mathrm{S}$ binding significantly $(p<0.05)$.
} 
Figure 2. GAP-43(1-10) peptide induces growth cone collapse from chick embryonic dorsal root ganglion neurons. $A$, Growth cone collapse by GAP43 peptide. Buffer (top panel) or $30 \mu \mathrm{M}$ GAP-43(1-10) peptide (bottom panel) was added to the culture medium for $60 \mathrm{~min}$ before fixation of explants of day 7 embryonic chick dorsal root ganglion neurons. The growth cones in the top panel are spread, and are typical of the majority of growth cones exposed to buffer. The growth cones in the bottom panel are collapsed, and are typical of those exposed to $30 \mu \mathrm{M}$ GAP-43(110) peptide. Analysis of greater than 1000 individual growth cones demonstrates that $23 \pm 2 \%$ of growth cones are collapsed in buffer-treated cultures, as opposed to $89 \pm 3 \%$ in $30 \mu \mathrm{M} \mathrm{GAP}$ 43(1-10) peptide-treated cultures. Scale bar, $10 \mu \mathrm{m}$. $B$, PTX sensitivity of the peptide effect. The indicated concentrations of GAP-43(1-10) peptide were included in the culture medium for 30 min and growth cone morphology from DRG explants was assessed as in $A$. The cultures had been treated $(\Delta)$ or not treated $(\square)$ with $100 \mathrm{ng} / \mathrm{ml}$ pertussis toxin for $2 \mathrm{hr}$ prior to the addition of peptide. Note that the $1-10$ peptide induces up to $90 \%$ growth cone collapse at $30 \mu \mathrm{M}$ concentration and that pertussis toxin shifts the dose-response curve to the right by a factor of 8 . The values shown are the means \pm SEM for five separate determinations. $C$, Time course of growth cone collapse and recovery. DRG explants were incubated with $10 \mu \mathrm{M}$ GAP-43(1-10) for various times and then analyzed for growth cone collapse ( $\square$ ). Note that collapse occurs within $30 \mathrm{~min}$ and decays slightly after $4 \mathrm{hr}$. To assess the reversibility of growth cone collapse, some cultures were incubated with $10 \mu \mathrm{M}$ GAP-43(1-10) for $1 \mathrm{hr}$ and then the medium was exchanged twice with non-peptide-containing medium. The incubation was continued for the indicated times before fixation and determination of the percentage of collapsed growth cones (O). Note that the percentage of collapsed growth cones returns to control values by $2 \mathrm{hr}$. The means \pm SEM from four separate experiments are indicated.
A
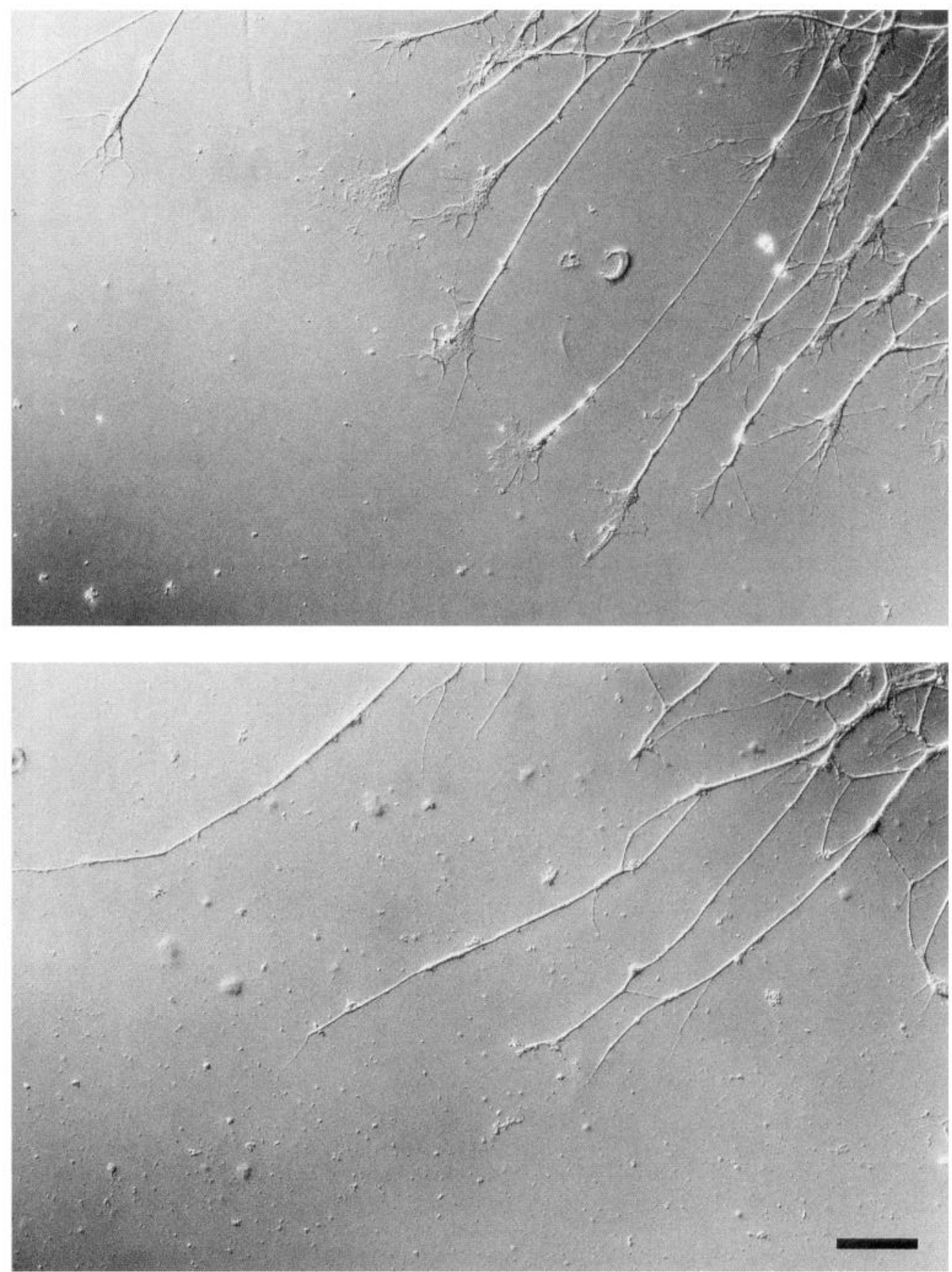

\section{GAP-43 peptides inhibit growth of DRG neurons}

Dorsal root ganglion (DRG) cell growth cones collapse when exposed to the direct G-protein stimulator mastoparan or to ligands associated with myelin and brain membranes, in a PTXsensitive manner (Igarashi et al., 1993). The GAP-43(1-10) peptide also causes growth cone collapse, in a dose-dependent fashion when added to the culture medium (Fig. $2 A, B$ ). Growth cone collapse occurs by $30-60 \mathrm{~min}$ and decays only slightly over $4 \mathrm{hr}$ (Fig. $2 C$ ). The small decrease in growth cone collapse after extended application could be due either to peptide degradation or to growth cone desensitization. If the peptide-containing growth medium is removed during the period of peak growth cone collapse, neuronal morphology returns to control levels within $2 \mathrm{hr}$ (Fig. 2C). Thus, the peptide-induced growth cone collapse is a reversible phenomenon. The average number of growth cones per ganglion was not altered by peptide addition (not shown).

Pertussis toxin blocks the peptide effect for peptide concentrations up to $30 \mu \mathrm{M}$, suggesting that a PTX-sensitive G-protein is directly affected by the peptides or is part of a signaling cascade stimulated by them (Fig. $2 B$ ). The incomplete blockade at higher 

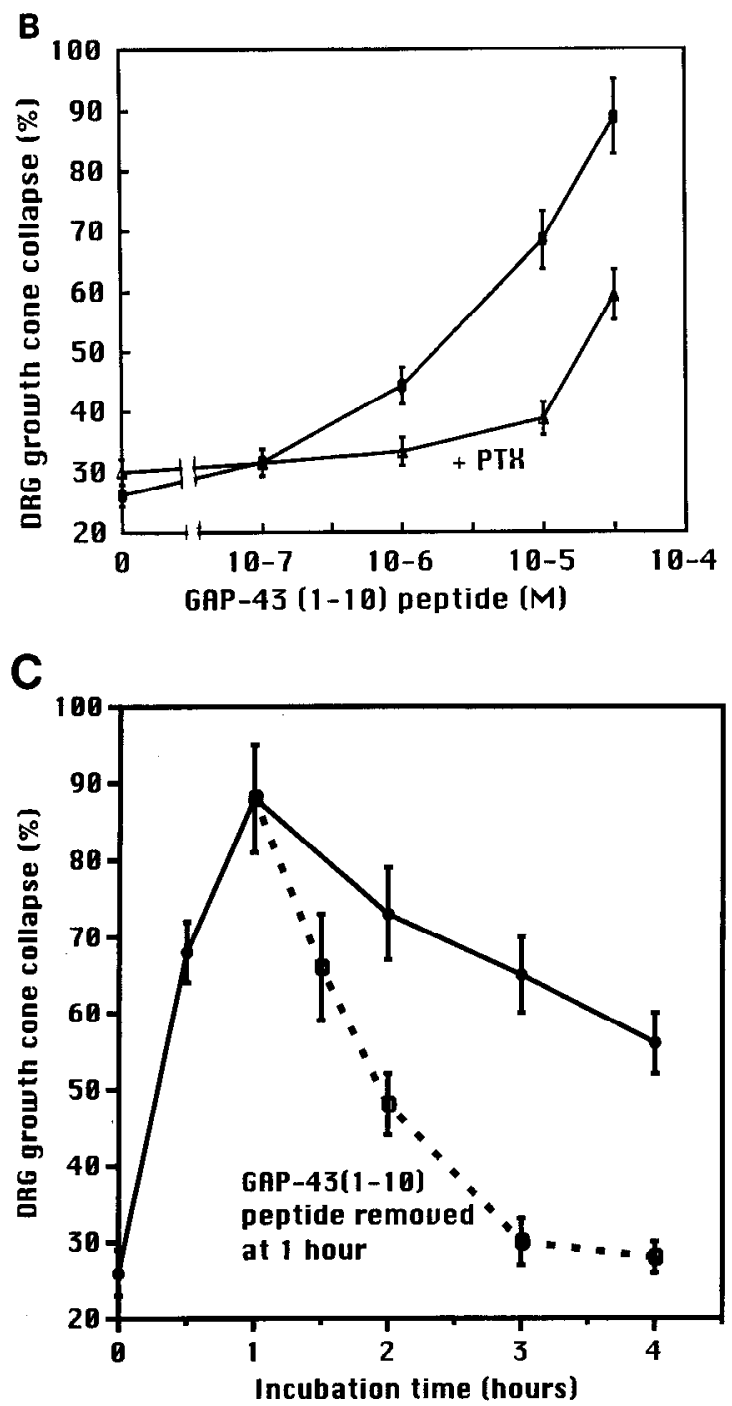

Figure 2. Continued.

peptide concentrations may be due to a PTX-insensitive mechanism of action for the peptide (see Fig. $1 B$ ), or to incomplete ADP-ribosylation.

The collapsing effect of the mutants and shorter peptides correlates with their $\mathrm{G}$-protein stimulating activity. Thus, the GAP43(1-6) peptide and the peptide with threonines substituted for the cysteines have no significant collapsing activity (Fig. 3). Substitution for K9 abrogates collapsing activity, and for R6 significantly reduces activity. The $1-10 \mathrm{R} 7$ peptide possesses activity intermediate between the wild-type 1-10 sequence and the other mutant peptides.

Growth cone collapse has been associated with diminished neurite growth (Raper and Kapfhammer, 1990). In order to examine peptide effects upon neurite extension, DRG neurons were dissociated and peptides added to the culture medium. After $6 \mathrm{hr}, 60 \%$ of the cells have regenerated neurites $>20 \mu \mathrm{m}$ in the absence of peptide (Fig. 4). The GAP-43 amino terminal peptides reduce neurite extension, with a potency $1-10>1-10 \mathrm{R} 7$ $>1-10 \mathrm{R} 6$. The 1-10K9, 1-10C3C4, and 1-6 peptides are not inhibitory. Thus, the potency of the GAP-43(1-10) peptides in causing both collapse of growth cones and inhibition of neurite outgrowth parallels their potency in stimulating $\mathrm{G}_{\mathrm{o}}$. The GAP$43(1-25)$ peptide causes neither growth cone collapse nor in-

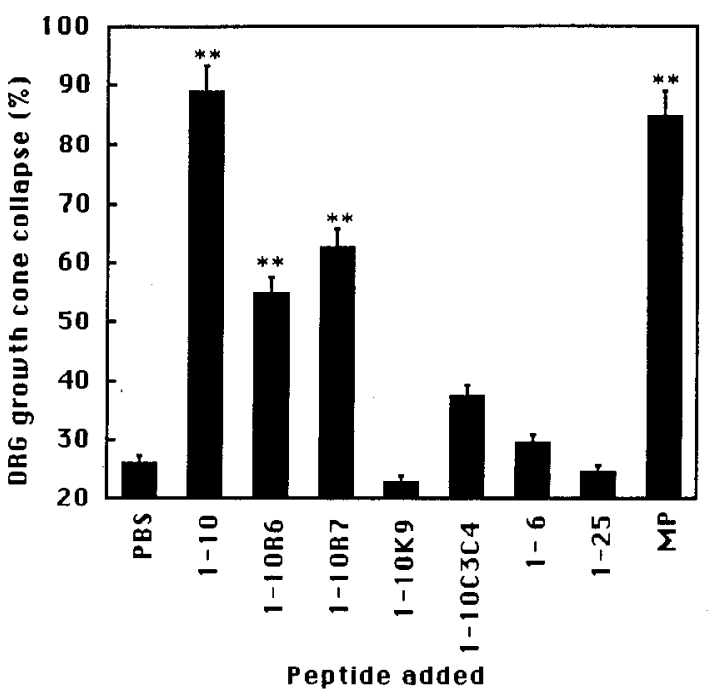

Figure 3. GAP-43 amino-terminal peptide sequence requirements for induction of growth cone collapse. The fraction of collapsed dorsal root ganglion growth cones after incubation with the indicated peptides at $30 \mu \mathrm{M}$ for $30 \mathrm{~min}$ is shown. Note that the GAP-43(1-10) peptide induces growth cone collapse but that the 1-25, 1-6, 1-10C3C4, and the $1-10 \mathrm{~K} 9$ mutants have no effect on growth cone collapse. The 1-10R6 and the 1-10R7 mutant peptides have collapsing activity but are not as effective as the wild-type 1-10 peptide. The values shown are the means \pm SEM for six separate determinations. ${ }^{* *}$, significantly different from PBS, $p$ $<0.01$.

hibition of neurite growth (Figs. 4, 5), perhaps because of decreased access to the cytosol (see below).

\section{Effect of GAP-43 amino terminal peptides on other neuronal cell types}

To test the generality of the peptide effects we added these reagents to a CNS-derived cell type. The GAP-43(1-10) peptide induces growth cone collapse in embryonic chick retinal neuron cultures (Fig. 5). The dose-response curve is nearly identical to that for DRG neurons.

N1E-1 15 neuroblastoma cells provide an established cell line that can extend neurites after exposure to differentiating agents. Mastoparan, the G-protein-stimulating wasp venom peptide (IIigashijima et al., 1988), stimulates N1E-115 outgrowth in a PTX-sensitive fashion, consistent with G-protein activation increasing N1E-115 outgrowth (see Fig. 7). This is the opposite of its action on DRG neurons (Fig. 4). Differentiated N1E-115 cells exposed to the GAP-43(1-10) peptide manifest longer neurites than do controls (Fig. 6). The action of the GAP-43(1-10) peptide is blocked by PTX, implying that it occurs via G-protein activation (Fig. 7). As for embryonic DRG neurons, the longer GAP-43(1-25) peptide has no effect (Fig. 6).

The sequence requirements within the GAP-43 peptide for increasing neurite outgrowth from N1E-115 cells exactly match those for stimulating purified $G_{o}$ and for inhibiting DRG outgrowth (Fig. 8). The 1-10R7 mutant has slight stimulating activity, but the 1-10R6,1-10K9, 1-10C3C4, and 1-6 peptides are inactive.

\section{GAP-43(1-25) peptide action requires permeabilization}

When added to the growth medium, the GAP-43(1-25) peptide does not alter growth cone collapse or neurite outgrowth (Figs. $3,4,6)$. This may be due to an intracellular site of action for 


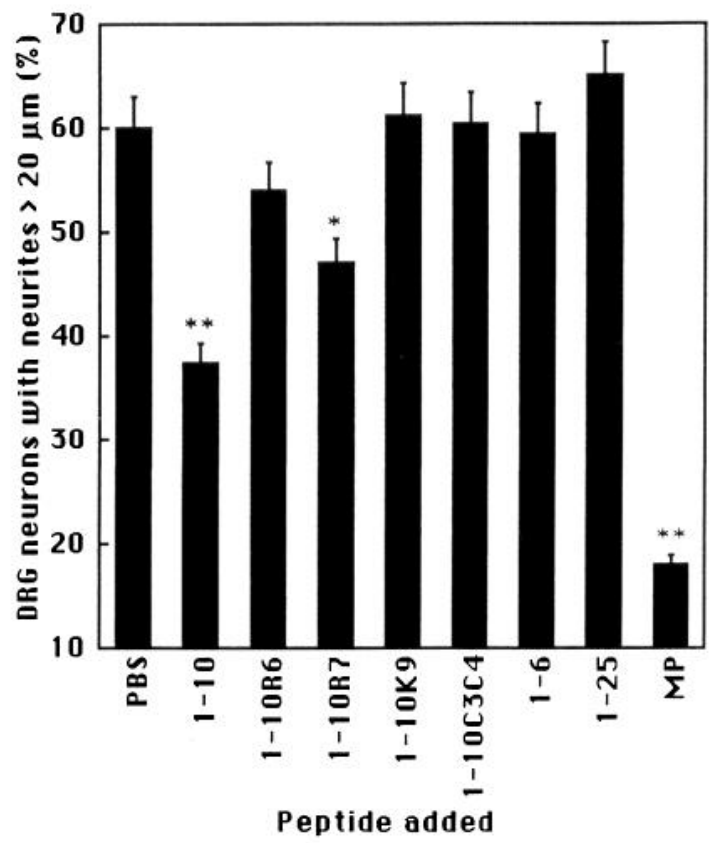

Figure 4. GAP-43(1-10) inhibits neurite outgrowth from dissociated dorsal root ganglion neuronal cultures. The indicated peptides $(10 \mu \mathrm{M})$ were added to the cultures of day 7 embryonic chick dorsal root ganglion neurons. Note that GAP-43(1-10) peptide and mastoparan decrease the fraction of neurons with a neurite longer than $20 \mu \mathrm{m}$. The $1-10 \mathrm{~K} 9$, 1-10C3C4, and the 1-6 mutant peptides are inactive. The 1-10R7 mutant is about $50 \%$ as effective as the wild-type $1-10$ peptide in decreasing the fraction of neurons with neurites greater than $20 \mu \mathrm{m}$, and the 1-10R6 peptide has a weak inhibitory effect on neurite outgrowth. The values shown are the means \pm SEM for four separate determinations. ${ }^{* *}$, significantly different from PBS, $p<0.01 ;{ }^{*}, p<0.05$.

the shorter GAP-43(1-10) peptide and failure of the longer GAP$43(1-25)$ peptide to gain access to the cell interior. N1E-115 neuroblastoma cells offer an opportunity to examine the necessity for peptide entry into the cell, because effective methods have been devised for the permeabilization of these cells (Shea et al., 1991). Permeabilization of N1E-115 cells by phospholipid and glycerol prior to addition of the GAP-43(1-25) peptide allows the longer peptide to stimulate neurite extension (Figs. 9, 10). After permeabilization, the GAP-43(1-25) peptide stimulates neurite outgrowth to the same degree as does the 1-10 peptide. This suggests that the GAP-43(1-25) peptide does not have access to the cytosol of unpermeabilized cells, and that its site of action in permeabilized cells is intracellular. In contrast, the mutated GAP-43(1-10) peptides, which do not stimulate $\mathrm{G}_{\mathrm{o}}$, remain inactive after permeabilization (Fig. 10). Their inactivity is therefore unlikely to be secondary to decreased access to the cytosol. The potency of the 1-10 peptide is increased about fivefold by cell permeabilization (Fig. 11), suggesting that GAP-43(1-10) has partial access to an intracellular site of action and that this can be increased by permeabilization.

We utilized a different method to permeabilize dissociated DRG neurons. Trituration has been shown to disrupt the membrane bilayer mechanically and allow entry of proteins into the cell (Borasio et al., 1989). Trituration of DRG cells with buffer prior to plating does not significantly alter neurite outgrowth during the first 4 hours in culture (Fig. 12). However, trituration of cells in the presence of GAP-43(1-25) peptide results in an inhibition of neurite outgrowth similar in magnitude to that

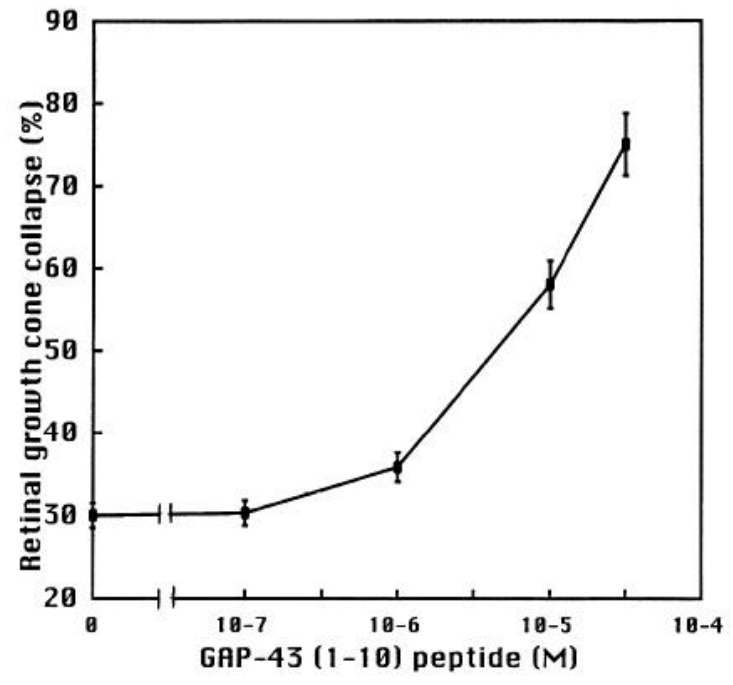

Figure 5. GAP-43(1-10) induces growth cone collapse in embryonic chick retinal neurons. GAP-43(1-10) peptide was present in the culture medium for $30 \mathrm{~min}$ at the indicated concentrations before fixation of day 7 embryonic chick retinal explants. Note that the GAP-43(1-10) peptide induces up to $75 \%$ growth cone collapse at $30 \mu \mathrm{M}$ concentration. The values shown are the means \pm SEM for five separate determinations.

caused by bath application of the GAP-43(1-10) peptide. Cell viability, as determined by trypan blue staining, is $85-90 \%$ after trituration with buffer, GAP-43(1-10) or GAP-43(1-25). Thus, the peptides do not affect cell survival, even after trituration.

We tested peptides from two other regions of GAP-43 for their effect on DRG and N1E-115 neurite outgrowth. Peptides from residues 53-69(A) and 210-226(B) do not stimulate $G_{o}$ (Strittmatter et al., 1990). These peptides have no effect on neurite outgrowth even in permeabilized cells (Figs. 8, 10, 12).

\section{Discussion}

\section{$G A P-43(1-10)$ peptide alters $G$-protein activity and neurite outgrowth}

We show here that peptides composed of the GAP-43 amino terminus can affect neurite length and growth cone collapse. Different cells are affected differently. The GAP-43(1-10) peptide causes collapse of DRG and retinal growth cones, and diminishes neurite length; the same peptide enhances neurite extension from neuroblastoma cells. Several experiments indicate that these effects are mediated by G-protein stimulation. The wasp venom peptide mastoparan, a known $G_{o} / G_{i}$ stimulator (Higashijima et al., 1988), affects these two cell types in the same manner as does the GAP-43(1-10) peptide. Pertussis toxin ADP-ribosylates $G_{o} / G_{i}$ (Gilman, 1987) and blocks the action of the GAP-43(1-10) peptide as a $G_{o}$ stimulator and as a regulator of neuronal growth. Furthermore, the order of potency of the peptides upon neurite growth (whether stimulatory or inhibitory, depending on the cell) parallels the order of potency of the peptides as $G_{0}$ stimulators.

There are several explanations for the effects of $G$ protein activation varying among cell types. In contrast to DRG and retinal neurons, N1E-115 cells might have a different complement of G-proteins subject to mastoparan and GAP-43(1-10) activation, or the same G-protein might interact with a different second messenger system, or the same second messenger system might have a different effect on neurite outgrowth.

It is not unexpected that reagents which alter G-protein ac- 
A
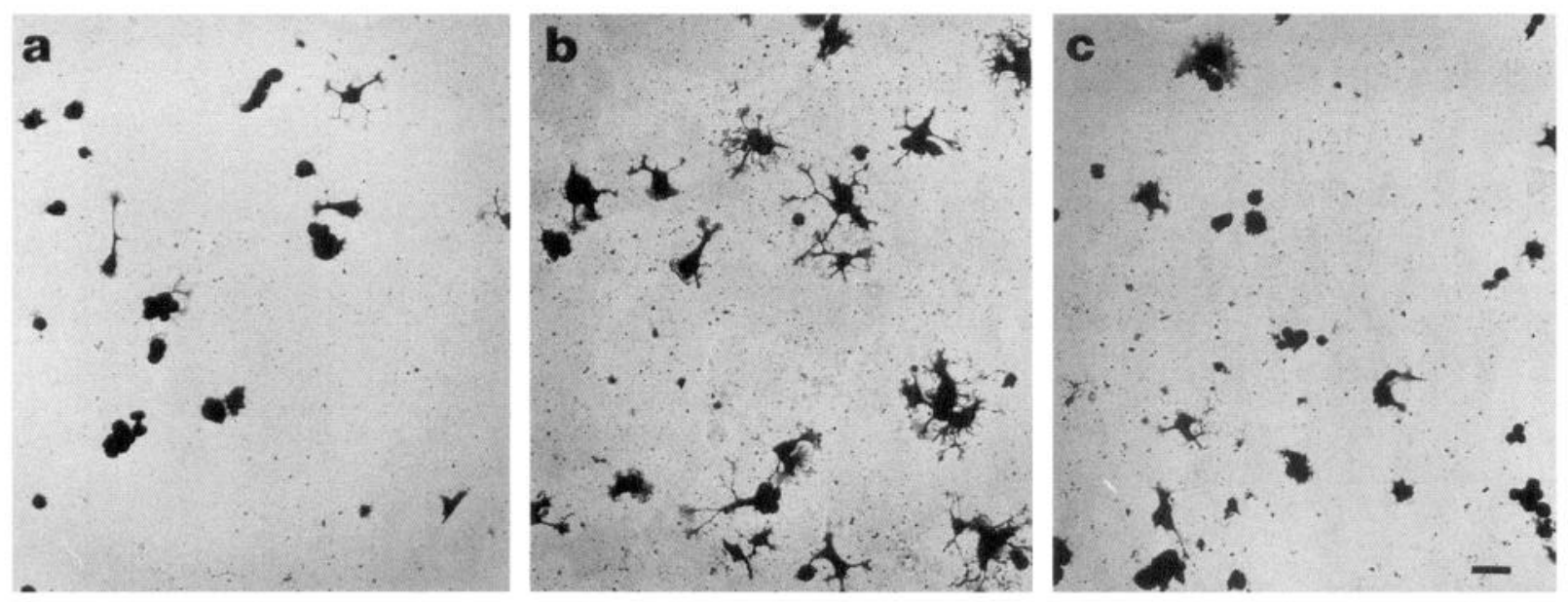

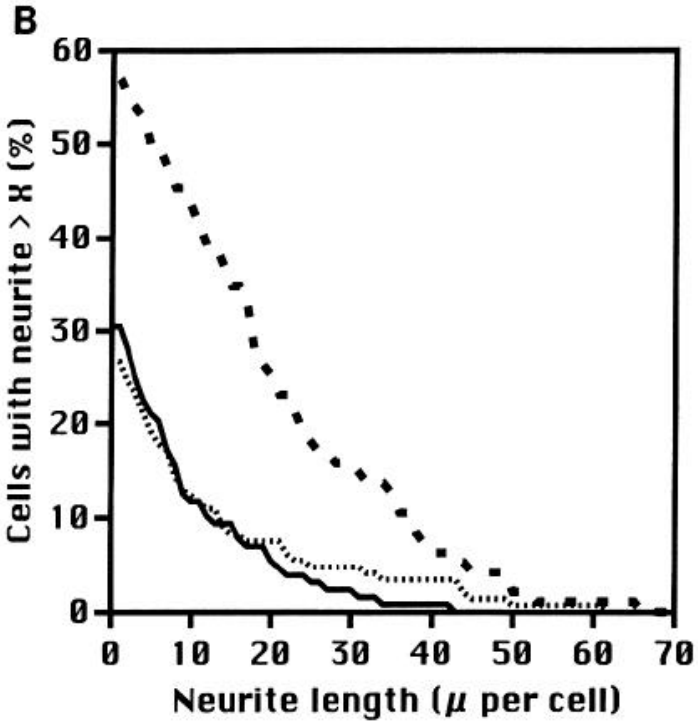

Figure 6. GAP-43(1-10) stimulates outgrowth from neuroblastoma cells. $A$, N1E-115 neuroblastoma cells were differentiated for $7 \mathrm{~d}$ in the presence of $2 \%$ DMSO. They were then cultured in the presence of buffer $(a), 120 \mu \mathrm{M}$ GAP43(1-10) peptide $(b)$, or $120 \mu \mathrm{M}$ GAP$43(1-25)$ peptide $(c)$. Note that the neurites are longer and more numerous in the sample incubated with the GAP43(1-10) peptide. Scale bar, $15 \mu \mathrm{m} . B$, The distribution of neurite length per cell is shown for an experiment of the type in $A$. The GAP-43(1-10) peptide (heavy dotted line) increases neurite extension, but the 1-25 peptide (dotted line) is indistinguishable from the control (solid line). This is one of 12 experiments with similar results. The average neurite length per cell is $3.6 \mu \mathrm{m}$ for control, $12.8 \mu \mathrm{m}$ for GAP-43(1-10), and $4.2 \mu \mathrm{m}$ for GAP-43(1-25) in this example. tivity might modulate neurite outgrowth. The nonhydrolyzable guanine nucleotide analog GTP $\gamma$ S stimulates G-proteins and decreases sympathetic neuron outgrowth; GDP $\beta$ S inhibits G-protein activation and stimulates outgrowth (Strittmatter et al., 1992). Expression of activated mutants of the $\alpha$ subunit of $\mathrm{G}_{\mathrm{o}}$ promote neurite outgrowth (Strittmatter et al., 1994a). Furthermore, ligands for G-protein-coupled receptors such as serotonin, dopamine, and thrombin induce growth cone collapse in particular cell types (Haydon et al., 1984; Lankford et al., 1988; Rodrigues and Dowling, 1990; Suidan et al., 1992). The neurite outgrowth modulating activity of both membrane-bound growth cone collapsing factors (Igarashi et al., 1993) and cell adhesion molecules (Doherty et al., 1991) can be abrogated by pertussis toxin treatment of neurons.

\section{GAP-43 amino-terminal peptides appear to act intracellularly}

GAP-43 amino-terminal peptides must gain entry into the cell if they are to act directly on intracellular G-proteins. The GAP$43(1-25)$ peptide data provide the strongest support for the notion that the GAP-43 peptides act intracellularly. The longer peptide can stimulate $G_{o}$ in vitro, but does not alter neurite outgrowth unless the cell is permeabilized. The GAP-43(1-10) peptide can affect both DRG and N1E-115 cell neurite extension without prior cell permeabilization, but its potency is increased by permeabilization. It is not clear by what route the 1-10 peptides gain entry into the cell. Disruption of neurites during dissection of DRG or retinal neurons, or during replating of N1E115 cells certainly might cause temporary breaches in the plasma membrane. For example, trituration allows the neuronal entry of small protein molecules, such as p21 ras and related proteins (Borasio et al., 1989; Ayala et al., 1990). It is also possible that the shorter peptides can cross the intact membrane. An Antennapedia homeobox polypeptide of 60 amino acid residues can enter motoneurons (Bloch-Gallego et al., 1993), and mastoparan is thought to cross the plasma membrane directly (Higashijima et al., 1988). We could not demonstrate this unequivocally for the GAP-43 peptides without creating radiolabeled active peptides, or isolating antibodies that distinguish peptides from native protein.

For several reasons, it is unlikely that mutant $1-10$ peptides are inactive due to decreased access to the cytosol. First, the sequence requirements for neurite regulation match those for 


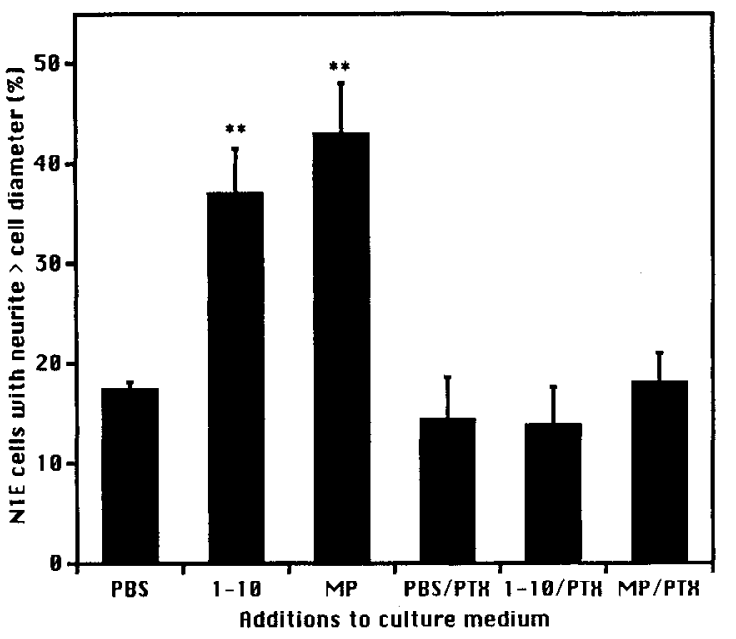

Figure 7. The stimulatory effect of GAP-43(1-10) peptide and mastoparan on neuroblastoma cell outgrowth is blocked by pertussis toxin. Cultures were incubated with buffer $(P B S), 120 \mu \mathrm{M}$ GAP-43(1-10), peptide or mastoparan $(M P)$ as described in Figure 4. Some cultures were pretreated for $2 \mathrm{hr}$ with $200 \mathrm{ng} / \mathrm{ml}$ pertussis toxin $(P T X)$ and pertussis toxin was included in the peptide incubation for these samples. Note that the GAP-43(1-10) peptide and mastoparan both increase the fraction of cells with a neurite greater than 1 cell diameter in length and that this effect is blocked by pertussis toxin pretreatment. The values shown are the means \pm SEM for four separate determinations. ${ }^{* *}$, significantly different from PBS, $p<0.01$.

G-protein stimulation. Second, the permeabilization procedure that allows entry of the 1-25 peptide does not promote the activity of the 1-10R6 or 1-10K9 peptides. Third, the 1-10R6 and $1-10 \mathrm{~K} 9$ are less charged than the $1-10$ peptide so that their crossing of a lipid bilayer presents a lower energy barrier.

\section{GAP-43 amino-terminal sequence requirements}

In designing these growth-modulating peptides, we focused upon alterations of the basic amino acid residues because peptide studies of the G-protein-activating regions of receptors suggested that an array of basic charges, B-B-X-B or B-B-X-X-B, is critical for stimulation (Okamoto et al., 1990, 1991a), and this region of GAP-43 includes the sequence Arg6-Arg7-Thr8Lys9. The activating domains in receptors differ from the amino terminus of GAP-43 by their inclusion of additional basic charges amino terminal to this canonical stretch. The order of potency of peptides, for both $G_{0}$ stimulation and effect upon neurite outgrowth, is $1-10 \approx 1-10 \mathrm{R} 7>1-10 \mathrm{R} 6 \approx 1-10 \mathrm{~K} 9$. Interestingly, $\mathrm{G}$-protein stimulation by peptides derived from receptors also is reduced to a greater degree by mutating the first or third basic amino acid of the B-B-X-B sequence than by mutating the second (Okamoto et al., 1991b). While this approach to choosing amino acids to mutate was useful in designing the GAP -43 peptides, the stretch of similarity to the receptor is so short that it could be fortuitous. Nonctheless, the sensitivity of GAP-43(1-10) peptide action to PTX implies some similarity between GAP-43(1-10) peptide and receptor activation of G-proteins.

The other GAP-43 amino acid residues critical to G-protein stimulation are cys 3 and cys 4 . In the intact protein, these are subject to palmitoylation, which enhances membrane binding (Skene and Virag, 1989; Zuber et al., 1989; Liu et al., 1991) and diminishes $G_{o}$ activation (Sudo et al., 1992). Their palmitoylation in the GAP-43(1-25) peptide also blocks its $G_{0}$-activating ability (Sudo et al., 1992). Threonine substitution for the cys-

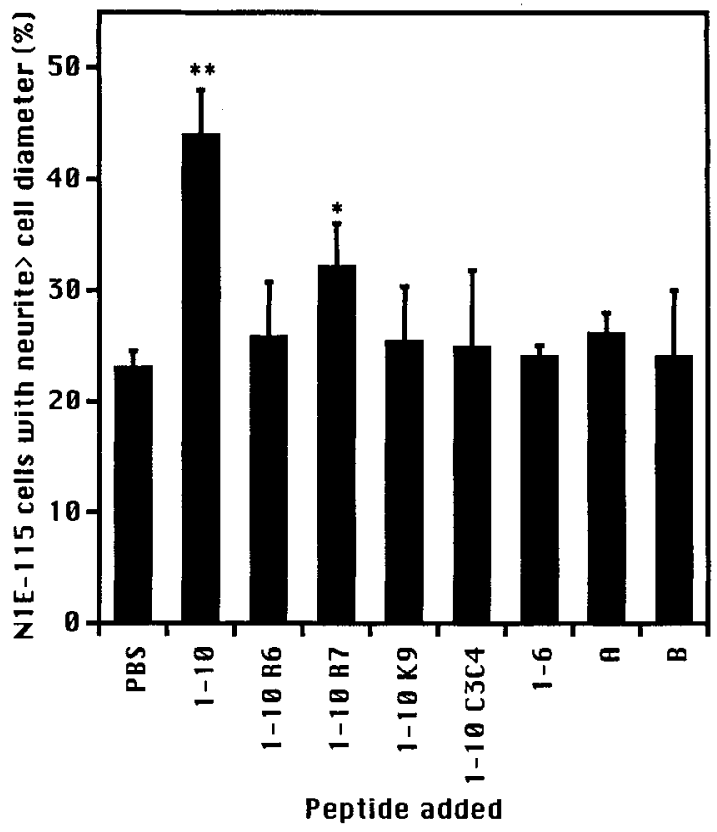

Figure 8. The neurite stimulating potential of mutant GAP-43 aminoterminal peptides. Differentiated N1E-115 cells were cultured in the presence of various GAP-43 peptides at $120 \mu \mathrm{M}$. The percentage of cells with a process longer than one cell body after four hr of incubation was quantitated. The mean values \pm SEM for 3-10 determinations are illustrated. Note that the GAP-43(1-10) peptide nearly doubles the percentage of positive cells and that the 1-10R7 peptide has a weak stimulatory action. All of the other peptides have no effect on neurite outgrowth. ${ }^{* *}$, significantly different from PBS, $p<0.01$; $^{*}, p<0.05$.

teines abrogates $\mathrm{G}_{\mathrm{o}}$-activating capability (Strittmatter et al., 1990), and blocks the peptide effect upon neurite growth.

\section{Relationship to endogenous $G A P-43$ protein}

For the reasons described above, the GAP-43 amino-terminal peptides are likely to act by stimulating an intracellular PTXsensitive G-protein. In vitro, both the protein and the peptide stimulate $G_{o}$, and appear to do so through a single site, with the protein being about 40 -fold more potent (Strittmatter et al., 1990 ). Does endogenous GAP-43 protein act by this mechanism in vivo? The ability of GAP-43 to regulate G-protein-based signal transduction when injected in Xenopus oocytes (Strittmatter et al., 1993) and when transfected into non-neuronal cells (Strittmatter et al., 1994a) supports the hypothesis that endogenous GAP-43 protein modulates G-protein activation. The 5-100 $\mu \mathrm{M}$ concentration at which the $1-10$ peptide has a graded effect on neurite outgrowth would have $\mathrm{G}_{0}$-stimulating activity equivalent to $0.1-2.5 \mu \mathrm{M}$ nonpalmitoylated, endogenous GAP-43 protein (Strittmatter et al., 1990). Since the total concentration of GAP -43 protein is about $2 \mu \mathrm{M}$ in whole brain and $5-20 \%$ is in the frec-sulfhydryl, nonpalmitoylated form (Skene and Virag, 1989), physiologic concentrations of GAP-43 are predicted to be roughly equivalent to those of the $1-10$ peptide. This is a crude estimate of the relative efficacy of the 1-10 peptide versus the endogenous protein because we cannot precisely measure intracellular peptide concentration, peptide palmitoylation levels (if any), or the degree of intracellular sequestration of GAP-43 protein and/or peptide from G-protein. GAP-43 protein is likely to have effects not shared by the peptide since the protein can bind calmodulin (Alexander et al., 1987), be phosphorylated by protein kinase C (Coggins and Zwiers, 
A
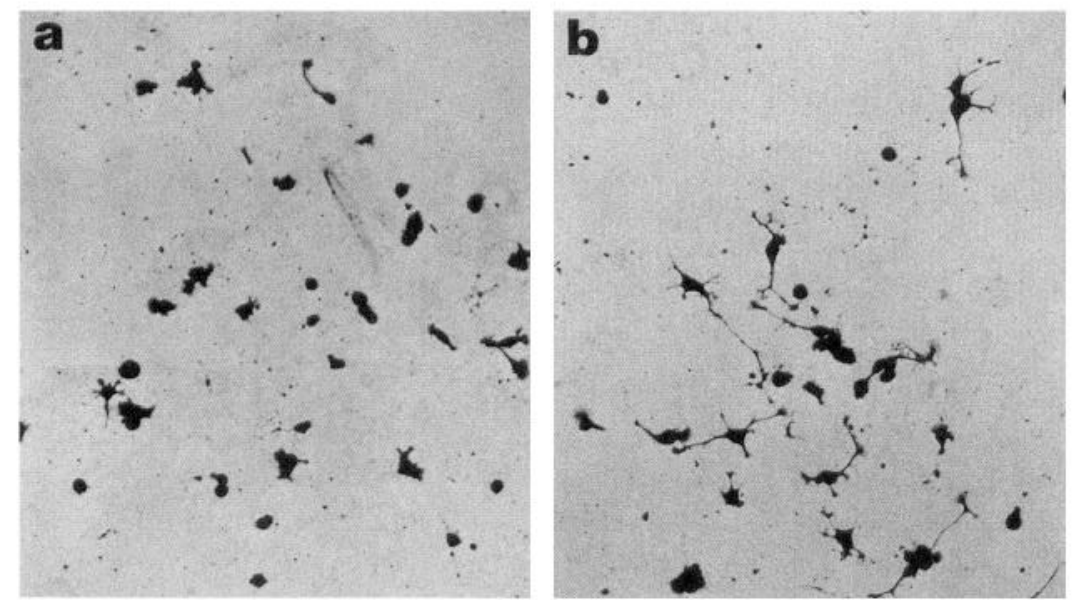

B



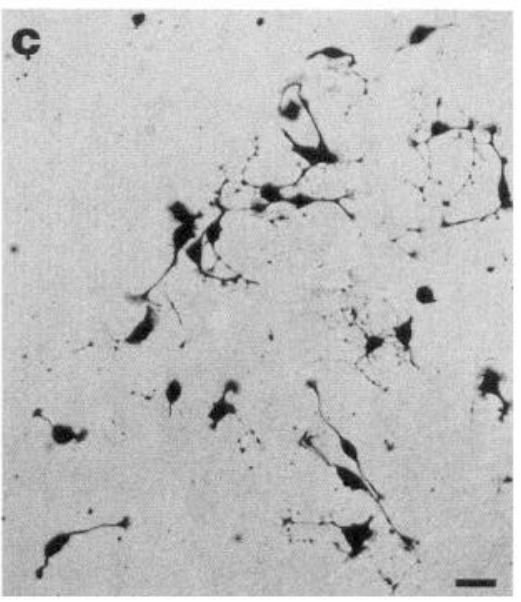

Figure 9. A GAP-43(1-25) peptide enhances neurite outgrowth from permeabilized cells. $A$, DMSO differentiated N1E-115 cells were briefly permeabilized by the method of Shea et al. (1992). These cells were then cultured for $5 \mathrm{hr}$ in the presence of buffer $(a)$, $120 \mu \mathrm{M}$ GAP-43(1-10) peptide $(b)$, or $120 \mu \mathrm{M}$ GAP-43(1-25) peptide (c). Note that after permeabilization, both the 1-25 and the 1-10 peptides stimulate neurite elongation. Scale bar, $15 \mu \mathrm{m} . B$, The distribution of neurite length per cell is shown for an experiment type in $A$. When the peptides are added after permeabilization, both the 1-25 peptide (dotted line) and the 1-10 peptide (heavy dotted line) increase the neurite length per cell above the control values (solid line). This is one of 10 experiments with similar results. The average neurite length per cell is $7.0 \mu \mathrm{m}$ for control, $12.4 \mu \mathrm{m}$ for GAP-43(1-10), and $15.9 \mu \mathrm{m}$ for GAP-43(1-25) in this example.
1989), and bind to actin filaments (Strittmatter et al., 1992). Clearly, the simplest extrapolation from the data here is that one of the actions of endogenous GAP-43 protein is similar to that of the peptide.

The stimulation of $\mathrm{G}_{\mathrm{o}}$ and the regulation of neurite outgrowth by GAP-43(1-10) is mildly sensitive to PTX, exhibiting blockade at low concentrations of peptide, but not at high concentrations. Our previous observation that $\mathrm{G}_{\mathrm{o}}$ stimulation by $1 \mu \mathrm{M}$ GAP-43 is not blocked by PTX (Strittmatter et al., 1991) might be due to a different mechanism of action for the peptide and the protein. More likely, these differences can be attributed to the use of GAP- 43 concentrations above saturation in the previous study, or to a greater PTX sensitivity for peptide as compared to protein action at one site resulting in $\mathrm{G}_{\mathrm{o}}$ stimulation.

\section{Growth cone signal amplification}

Many receptor proteins which act via G-proteins have been identified, and some are known to be present in the growth cone and to induce growth cone collapse. When injected into Xenopus oocytes, GAP-43 not only directly activates a G-protein cascade, but also sensitizes the cell to ligands for G-protein-coupled receptors (Strittmatter et al., 1993). By analogy, exogenous GAP43 peptide and/or endogenous GAP-43 protein might increase the "gain" of a growth cone signal transduction system for ligands in the extracellular environment. Such ligands might either stimulate or inhibit neurite extension. During development and regeneration, signal amplification is critical, since the contact of a single filopodium with appropriate pathways or targets can redirect the entire growth cone (Kapfhammer and Raper, 1987).

Whether or not these peptides act at molecular sites identical to the native protein, they represent a novel class of neurite outgrowth modulating compounds. It will be of interest to test their effects on nerve regeneration in whole animals because they might lead to a class of therapeutic agents to modify nervous system development, plasticity, and regeneration. 


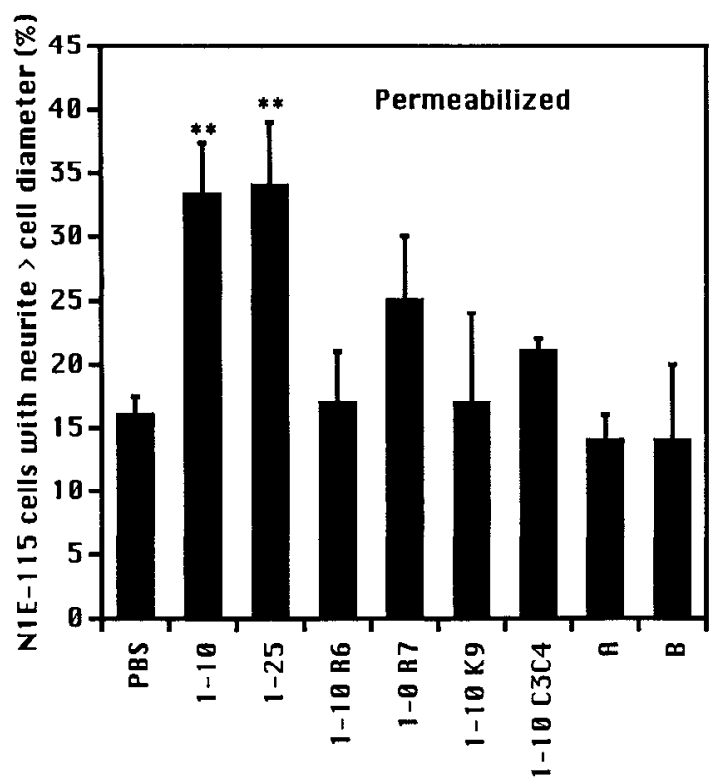

Peptide added

Figure 10. The neurite stimulating potential of mutant GAP-43 amino-terminal peptides in permeabilized N1E-115 cells. Differentiated N1E-115 cells were permeabilized and then cultured in the presence of various GAP-43 peptides at $120 \mu \mathrm{M}$ for $4 \mathrm{hr}$. The percentage of cells with a neurite longer than one cell diameter was measured. Note that the pattern of activity is identical to that in Figure 8 except that the GAP-43(1-25) is active after permeabilization. The mean values \pm SEM for 3-10 determinations are illustrated. ${ }^{* *}$, significantly different from PBS, $p<0.01$.

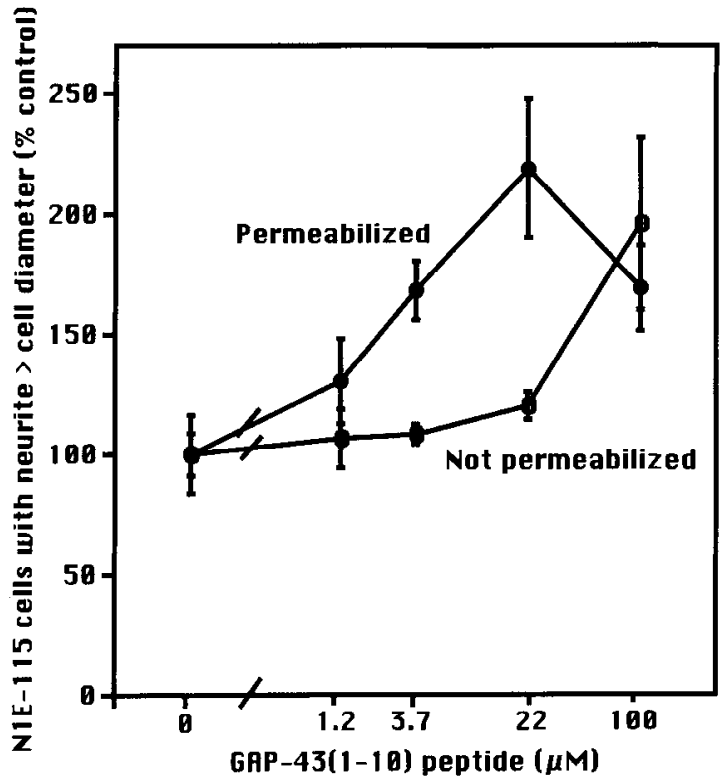

Figure 11. The potency of GAP-43(1-10) for stimulation of NIE-115 outgrowth is increased by permeabilization. The percentage of differentiated N1E-115 cells which had extended a neurite greater than one cell diameter was determined after incubation in the presence of the indicated concentrations of the GAP-43(1-10) peptide. Cells were either permeabilized $(\bullet)$ or not permeabilized $(O)$ at the time of peptide addition. Note that for unpermeabilized cells $30-100 \mu \mathrm{M}$ peptide is required to stimulate outgrowth, but that for permeabilized cells as little as $4 \mu \mathbf{M}$ peptide increased outgrowth significantly above buffer control levels $(p<0.01)$. The values were normalized for the percentage of cells with neurites $>$ cell diameter in the absence of peptide, which was $12 \%$ for the permeabilized cells and $24 \%$ for the unpermeabilized cells. The mean values \pm SEM for two to five determinations are illustrated.

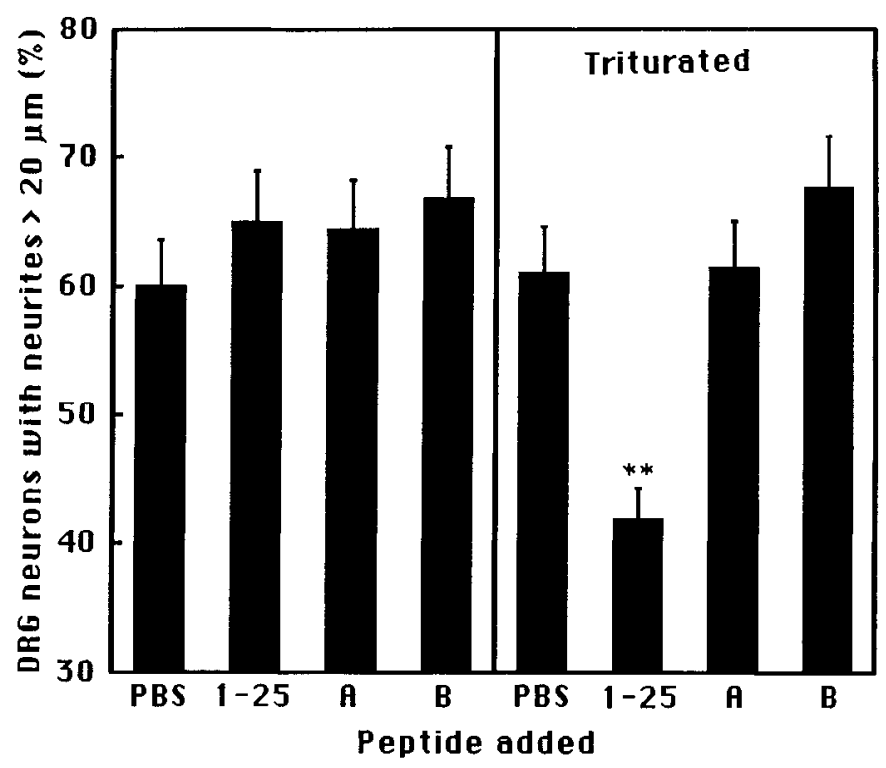

Figure 12. GAP-43(1-25) inhibits neurite outgrowth when triturated with DRG neurons. DRG neurons were triturated in the presence of buffer or $50 \mu \mathrm{M}$ GAP-43 peptides, and then dissociated cells were plated in the presence of buffer or $10 \mu \mathrm{M}$ GAP-43 peptides. The PBS samples were never exposed to peptide. GAP-43 peptides were added before trituration (left) or after trituration (right). Four hours after plating the percentage of cells with neurites longer than $20 \mu \mathrm{m}$ was determined. Note that the GAP-43(1-25) peptide inhibits outgrowth only when present during trituration. The values shown are the means \pm SEM for five separate experiments. ${ }^{* *}$, significantly different from PBS, $p<0.01$.

\section{References}

Alexander KA, Cimler BM, Meiri KE, Storm DR (1987) Regulation of calmodulin binding to P-57. J Biol Chem 262:6108-6113.

Alexander KA, Wakim BT, Doyle GS, Walsh KA, Storm DR (1988) Identification and characterization of the calmodulin-binding domain of neuromodulin, a neurospecific calmodulin-binding protein. $J$ Biol Chem 263:7544-7549.

Ayala J, Touchot N, Zahraoui A, Tavitian A, Prochiantz A (1990) The product of rab2, a small GTP-binding protcin, incrcases neuronal adhesion, and neurite growth in vitro. Neuron 4:797-805.

Baetge EE, Hammang JP (1991) Neurite outgrowth in PC12 cells deficient in GAP-43. Neuron 6:21-30.

Benowitz LI, Routtenberg A (1987) A membrane phosphoprotein associated with neural development, axonal regeneration, phospholipid metabolism and synaptic plasticity. Trends Neurosci 10:527532.

Benowitz LI, Apostolides PJ, Perone-Bizzozero N, Finkelstein SJ, Zwiers $\mathrm{H}$ (1988) Anatomical distribution of the growth-associated protein GAP-43/B-50 in the adult rat brain. J Neurosci 8:339-352.

Bloch-Gallego E, Le Roux I, Joliot AH, Henderson CE, Prochiantz A (1993) Antennapedia homeobox peptide enhances growth and branching of embryonic chicken motoneurons in vitro. $\mathrm{J}$ Cell Biol 120:485-492.

Borasio GD, John J, Wittinghofer A, Barde YA, Sendtner AM, Heumann $R$ (1989) ras p2l protein promotes survival and fiber outgrowth of cultured embryonic neurons. Neuron 2:1087-1096.

Coggins PJ, Zwiers H (1989) Evidence for a single protein kinase C phosphorylation site in rat brain protein B-50. J Neurochem 53:18951901.

Doherty P, Ashton SV, Moore SE, Walsh FS (1991) Morphoregulatory activities of NCAM and N-Cadherin can be accounted for by $\mathrm{G}$ protein-dependent activation of $\mathrm{L}$ - and $\mathrm{N}$-type neuronal $\mathrm{Ca}^{2+}$ channels. Cell 67:21-33.

Gilman AG (1987) G proteins: transducers of receptor-generated signals. Annu Rev Biochem 56:615-649.

Grabczyk E, Zuber MX, Federoff HJ, Ng SC, Pack A, Fishman MC (1990) Cloning and characterization of the rat gene encoding GAP43. Eur J Neurosci 2:822-827. 
Haydon PG, McCobb DP, Kater SB (1984) Serotonin selectively inhibits growth cone motility and synaptogenesis of specific identified neurons. Science 226:561-564.

Higashijima T, Uzu S, Nakajima T, Ross EM (1988) Mastoparan, a peptide toxin from wasp venom, mimics receptors by activating GIPbinding regulatory protein (G proteins). J Biol Chem 263:6491-6494.

Igarashi M, Strittmatter SM, Vartanian T, Fishman MC (1993) Mediation by $\mathrm{G}$ proteins of signals that cause collapse of growth cones. Science 259:77-79.

Kapfhammer JP, Raper JA (1987) Collapse of growth cone structure on contact with specific neurites in culture. J Neurosci 7:201-212.

Lankford KL, DeMello FG, Klein WL (1988) D1-type dopamine receptors inhibit growth cone motility in cultured retina neurons: evidence that neurotransmitters act as morphogenic growth regulators in the developing central nervous system. Proc Natl Acad Sci USA 95:2839-2843.

Oestreicher AB, Van Dongen CJ, Zwiers H, Gispen WH (1983) Affinity-purified anti-B-50 protein antibody: interference with the function of the phosphoprotein B-50 in synaptic plasma membranes. Neurochem 41:331-340.

Okamoto T, Katada T, Murayama Y, Ui M, Nishimoto I (1990) A simple structure encodes $\mathrm{G}$ protein-activating function of the IGF II/ mannose 6-phosphate receptor. Cell 62:709-717.

Okamoto $T$, Murayama $Y$, Hayashi $Y$, Inagaki $M$, Ogata $E$, Nishimoto I (1991a) Identification of a $\mathrm{G}_{\mathrm{s}}$ activator region of the $\beta_{2}$-adrenergic receptor that is autoregulated via protein kinase $A$--dependent phosphorylation. Cell 67:723-730.

Okamoto T, Ohkumi Y, Ogata E, Nishimoto I (1991b) Distinct mode of $G$ protein activation due to single residue substitution of active IGF-II receptor peptide Arg2410-Lys2423: evidence for stimulation acceptor region other than C-terminus of $\mathrm{G}_{\mathrm{i} \alpha}$. Biochem Biophys Res Commun 179:10-16.

Raper JA, Kapthammer JP (1990) The enrichment of a neuronal growth cone collapsing activity from embryonic chick brain. Neuron 2:21-29.

Rodrigues PS, Dowling JE (1990) Dopamine induces neurite retraction in retinal horizontal cells via diacylglycerol and protein kinase C. Proc Natl Acad Sci USA 87:9693-9697.

Shea TB, Perrone-Bizzozero NI, Beermann ML, Benowitz LI (1991) Phospholipid-mediated delivery of anti-GAP-43 antibodies into neuroblastoma cells prevents neuritogenesis. J Neurosci 11:1685-1690.

Skene JHP (1989) Axonal growth-associated proteins. Annu Rev Neurosci $12: 127-156$.
Skene JHP, Virag I (1989) Posttranslational membrane attachment and dynamic fatty acylation of a neuronal growth cone protein, GAP43. J Cell Biol 108:613-624.

Strittmatter SM (1992) GAP-43 as a modulator of G protein transduction in the growth cone. Perspect Dev Neurobiol 1:13-19.

Strittmatter SM, Fishman MC (1991) The neuronal growth cone as a specialized transduction system. Bioessays 13:127.

Strittmatter SM, Valenzuela D, Kennedy TE, Neer EJ, Fishman MC (1990) $G_{0}$ is a major growth cone protein subject to regulation by GAP-43. Nature 344:836-841.

Strittmatter SM, Valenzuela D, Sudo Y, Linder ME, Fishman MC (1991) An intracellular guanine nucleotide release protein for $\mathrm{G}_{0} . \mathrm{J}$ Biol Chem 266:22465-22471.

Strittmatter SM, Vartanian T, Fishman MC (1992) GAP-43 as a neuronal plasticity protein in neuronal form and repair. J Neurobiol 23 : 507-520.

Strittmatter SM, Cannon SC, Ross EM, Higashijima T, Fishman MC (1993) GAP-43 augments $G$ protein-coupled receptor transduction in $X$. laevis oocytes. Proc Natl Acad Sci USA 90:5327-5331.

Strittmatter SM, Fishman MC, Zhu X-P (1994a) Activated mutants of the $\alpha$ subunit of $\mathrm{G}_{\mathrm{o}}$ promote an increased number of neurites per cell. J Neurosci 14:2327-2338.

Strittmatter SM, Valenzuela D, Fishman MC (1994b) An amino terminal domain of the growth-associated proteion GAP-43 mediates its effects on filopodial formation and cell spreading. J Cell Sci 107: 195-204.

Sudo Y, Valenzuela D, Beck-Sickinger AB, Fishman MC, Strittmatter SM (1992) Palmitoylation alters protein activity: blockade of $G_{0}$ stimulation by GAP-43. EMBO J 11:2095-2102.

Suidan HS, Stone SR, Hemmings BA, Monrad D (1992) Thrombin causes neurite retraction in neuronal cells through activation of cell surface receptors. Neuron 8:363-375.

Yankner BA, Benowitz LI, Villa-Komaroff L, Neve RL (1990) Transfection of PC1 2 cells with the human GAP- 43 gene: effects on neurite outgrowth and regeneration. Mol Brain Res 7:39-44.

Zuber MX, Goodman DW, Karns LR, Fishman MC (1989a) The neuronal growth associated protein GAP-43 induces filopodial formation in non-neuronal cells. Science 244:1193-1195.

Zuber MX, Strittmatter SM, Fishman MC (1989b) A membranetargeting signal in the amino terminus of the neuronal protein GAP43. Nature $341: 345-348$. 